\title{
Geriatrics intensive care unit: Outcome and risk factors for in hospital mortality
}

\author{
Salma M. S. El Said
}

Geriatrics and Gerontology Department, Faculty of Medicine, Ain Shams University, Cairo, Egypt: salmasaied777@gmail.com

Received 29 August 2013; revised 29 September 2013; accepted 7 October 2013

Copyright (C) 2013 Salma M. S. El Said. This is an open access article distributed under the Creative Commons Attribution License, which permits unrestricted use, distribution, and reproduction in any medium, provided the original work is properly cited.

\begin{abstract}
OBJECTIVES: To evaluate outcome and risk factors, particularly the (APATCHE II) score in elderly patients after admission to a geriatrics intensive care unit (ICU). Methods: A cross sectional study of patients $\geq 60$ years admitted to the intensive care unit (ICU) of the Geriatrics department at Ain Shams University Hospital over 2 years period. We recorded age, sex, previous medical history, primary diagnosis, date of admission and discharge or death and APACHE II score on admission. Results: 202 patients admitted to the ICU were studied. The mean ICU mortality rates for these patients were $(32,5 \%)$, the mean APATCHE II score was (19.07). 27.3\% of patients who died had hypokalemia and $43.2 \%$ had hyponatremia. Conclusion: ICU mortality rate are higher in elderly patients particularly with long ICU stay and hyponatremia.
\end{abstract}

Keywords: APATCHE II Score; Geriatrics ICU; Hyponatremia

\section{INTRODUCTION}

In many countries average age and life expectancy of the population are increasing [1]. Because of this, a growing number of older patients are being admitted to the intensive care unit (ICU). There is some evidence to suggest that age is a restrictive factor for ICU admission

\footnotetext{
*Author contributions: Study concept and design: Salma M. S. El Said; Analysis and interpretation of data: Salma M. S. El Said; Drafting of the manuscript: Salma M. S. El Said; Critical revision of the manuscript for important intellectual content: Salma M. S. El Said; Statistical analysis: Salma M. S. El Said. All authors have no financial interests related to the material in the manuscript. This study received no financial support.

Implications for health policy: The aim of the study was to evaluate the outcome and risk factors for in hospital mortality in geriatrics intensive care unit.
}

$[2,3]$ and that it determines treatment intensity [4,5]. However, even though an increased risk of mortality accompanies old age [6-10], most studies suggest that age alone does not represent a strong predictor for mortality [4]. We have studied risk factors for in hospital mortality in elderly patients, in particular we have evaluated the Acute physiology and chronic health evaluation (APATCHE II) scoring system [11].

\section{MATERIALS AND METHODS}

A single center, cross sectional study was carried out in the ICU of the Geriatrics Department at Ain Shams University Hospital in Cairo Egypt from April1/2011 through April 1/2013.

During this period of two years, all patients admitted in the ICU were recruited for the study. After admission, the patients were divided into survival group (those who were discharged from the ICU after improvement) and non survival group (those who died in the ICU).

The study was approved by the University and Hospital Ethics Committees.

Data collection was done for all participants including patients' demographics and medical history, length of stay in the ICU.

The Acute Physiology and Chronic Health Evaluation (APACHE) II score incorporates 12 physiologic variables, age, and an assessment of chronic diseases in individual patients.

Blood sample was collected at admission to calculate Serum sodium $(136-142 \mathrm{mEq} / \mathrm{L})$ and serum potassium $(3.8-5 \mathrm{mEq} / \mathrm{L})$.

\section{STATISTICAL ANALYSIS}

Data was analyzed using the statistical program SPSS for window, Release 16. All values are reported as mean \pm SD., two tailed students t-test is used for continuous variables. Chi-square and Fisher's exact tests were used to compare categorical variables between survival and 
non survival group. Multiple logistic regression analysis was performed to determine the independent risk factors for in hospital mortality. Relative risk is given with the 95\% confidence interval (CI). Pearson's correlation coefficient and linear regression were used to evaluate the in hospital risk factors for mortality. A $p$ value of $<0.05$ was considered as statistically significant.

\section{RESULTS}

A total of 202 patients' $\geq 60$ years old were studied. The mean age of the studied groups was 69.9 years. The study included 68 (33.7\%) males and 134 (66.3\%) females. $31.6 \%$ of patients were admitted with diabetes mellitus complications, $19,8 \%$ with cardiovascular complications, $13.8 \%$ with disturbed level of conscious and $12.8 \%$ with pulmonary complications.

114 patients $(56.4 \%)$ were discharged from ICU after improvement while 88 patients $(43.6 \%)$ were died during ICU stay. The mean lengthy of ICU stay was 7.03 days among the survival group and 10.15 days among the non survival group with high statistical significant difference $(p=0.004)$ (Table 1).

The mean APATCHE II score for all subjects was 19.07 and among the non-survival group was 22.77 . The score was significantly higher in non survival compared with survival group with high statistical significant difference $(p=0.000)$ (Table 1).

$68.2 \%$ of the non-survival group were females with no statistical significant difference. There was negative correlation between age and length of ICU stay with no statistical significant difference. The mean death rate for all subjects was $32.5 \%$ and $42.5 \%$ among the non-survival group the rate was significantly higher in non-survivals compared with survivals with high statistical significant difference $(p=0.000)$. There was a positive correlation between age and death rate with no statistical significant difference (Table 2).

$27.3 \%$ of non-survival group had hypokalemia and $43.2 \%$ had hyponatremia with no statistical significant difference (Table 3).

\section{DISCUSSION}

Age was strongly associated with the severity of illness scores [12-14], but even when adjusted for the degree of physiological impairment, age remained a strong predictor of mortality. This finding is consistent with previous studies, which evaluated the severity of illness upon admission to the ICU through the APS application and differs from many others that found no association between age and mortality [15,16]. Although age has frequently been examined as a prognostic factor related to mortality of patients admitted to the ICU, few prior studies have provided quantitative estimates of increased risk associated with specific age intervals. Most of these studies adopted different selection criteria when defining an elderly population, mainly ranging from 60 to 85 years of age and not differentiating between various age intervals $[15,17]$. In the current study, there is positive correlations between age and death rate among the studied group and the mean age of the studied group was 69.9 years. Esteban et al. created a different model to determine a threshold of age that could best discriminate for ICU survival [18]. However, our goal was to evaluate outcome and risk factors for in hospital mortality in elderly patients after ICU admission.

Recent studies have revealed important data related to the short- and long-term outcomes of elderly patients. In a study done by Castillo et al. they show that ICU mortality rates for patients aged $\geq 75$ years, varying from $22 \%$ to $31 \%$, reflect differences in underlying diseases and severity of illness on admission and are mostly related to underlying disease, severity of illness, nosocomial infection, evolving organ dysfunction and quality of care after discharge from the ICU [19-21]. Acute physiological impairment and diagnosis have much larger relative effects on prognosis than age [22]. In the current study, death rate was higher in non survival group with high statistical significant difference.

Table 1. Patients characteristics.

\begin{tabular}{|c|c|c|c|c|}
\hline & \multicolumn{2}{|c|}{ Studied groups } & & \\
\hline & Survival group $\mathrm{N}=114$ & Non survival group $\mathrm{N}=88$ & & \\
\hline Age (years) & Mean \pm SD $69.3 \pm 9.3$ & Mean \pm SD $70.7 \pm 9.1$ & $\mathrm{t}=1.103$ & $p=0.271$ \\
\hline \multirow[b]{2}{*}{ Sex } & Males $40(35.1 \%)$ & Males $28(31.8 \%)$ & \multirow[b]{2}{*}{$\mathrm{X}^{2}=0.238$} & \multirow{2}{*}{$p=0.626$} \\
\hline & & & & \\
\hline Length of ICU stay (days) & Mean \pm SD $7.03 \pm 4.46$ & Mean \pm SD $10.15 \pm 10.43$ & $\mathrm{t}=2.876$ & $p=0.004$ \\
\hline APATCHE II score & Mean \pm SD $16.22 \pm 4.4$ & Mean \pm SD $22.77 \pm 6.86$ & $\mathrm{t}=8.171$ & $p=0.000$ \\
\hline Death rate & Mean \pm SD $24.87 \pm 12.1$ & Mean \pm SD $42.5 \pm 19.7$ & $\mathrm{t}=7.84$ & $p=0.000$ \\
\hline
\end{tabular}


Table 2. Correlation between age and length of ICU stay, death rate.

\begin{tabular}{ccc}
\hline & Length of ICU stay & Death rate \\
\hline Age & $\mathrm{r}=-0.067 p=0.341$ & $\mathrm{r}=0.130 p=0.065$ \\
\hline
\end{tabular}

Table 3. Relation between serum sodium, potassium and patients outcome.

\begin{tabular}{|c|c|c|c|c|}
\hline & & \multicolumn{2}{|c|}{ Studied groups } & \\
\hline & & \multicolumn{2}{|c|}{$\begin{array}{cc}\text { Survival } & \text { Non-survival } \\
\text { group } \mathrm{N}=114 & \text { group } \mathrm{N}=88\end{array}$} & \\
\hline $\begin{array}{l}\text { Serum } \\
\text { sodium }\end{array}$ & Low & $62(54.4 \%)$ & $38(43.2 \%)$ & \\
\hline$(\mathrm{mEq} / \mathrm{L})$ & Normal & $48(42.1 \%)$ & $50(56.8 \%)$ & $\mathrm{F}=6.56 p=0.038$ \\
\hline $\begin{array}{c}\text { Mean } \pm \text { SD } \\
134 \pm 7.6\end{array}$ & High & $4(3.5 \%)$ & $0(0.0 \%)$ & \\
\hline Serum & Low & $22(19.3 \%)$ & $24(27.3 \%)$ & \\
\hline $\begin{array}{c}\text { Potassium } \\
(\mathrm{mEq} / \mathrm{L}) \\
\text { Mean } \pm \mathrm{SD}\end{array}$ & Normal & 78 (68.4\%) & $52(59.1 \%)$ & $\begin{array}{c}\mathrm{F}= \\
2.130\end{array}$ \\
\hline $4.1 \pm 1.1$ & High & $14(12.3 \%)$ & $12(13.6 \%)$ & \\
\hline
\end{tabular}

Risk prediction in elderly patients will become increasingly important over the next decade as the population age. More accurate prognosis predictions in critically ill elderly patients may help to decrease morbidity, improve therapeutic strategies and increase patients' quality of life [23]. The APACHE II score measures severity of illness using a numerical score based on physiological variables selected because of their known impact on mortality: a more ill patient has more deranged values and a higher APACHE II score [24]. As in other studies [25-28] the APACHE II score was sufficiently accurate in the present study to be able to predict mortality in individual patients. The APACHE II score alone can, therefore, is used to predict the outcome of critically ill elderly patients on admission. In the current study the mean APATCHE II score was higher among the non-survival group with high statistical significant difference. Disturbances in plasma sodium concentrations are a common clinical problem in patients admitted to the intensive care unit. Many cases of dysnatremia are acquired after a patient is admitted to the ICU, and the presence of dysnatremia is associated with poor prognosis. A recent study involving 151,486 adult patients from 77 intensive care units over a period of 10 years has demonstrated that many cases of dysnatremia are acquired in the intensive care unit, and that the severity of dysnatremia is associated with poor outcome in a graded fashion [29]. Another study on the ICU patients with dysnatremias corroborated these findings, reporting that ICU-acquired hyponatremia and ICU-acquired hypernatremia were associated with increased mortality [30]. In the current study $(43.2 \%)$ of the non survivals group had hyponatremia.

\section{CONCLUSION}

Critically ill elderly patients have multiple system disorders and complications. We found that mortality in elderly patients was higher among those with prolonged ICU stay. The independent factors associated with the highest risk of death are the factors affecting the APATCHE II. The APACHE II score has excellent capability to predict mortality on the basis of values measured within the first $24 \mathrm{~h}$ after admission. This score does not, however, take into account the many factors that can influence patient outcome during the course of an ICU stay, so proper evaluation of changes in patient status over time is also important.

\section{REFERENCES}

[1] Roch, A., Wiramus, S., Pauly, V., Forel, J.M., Guervilly, C., Gainnier, M. and Papazian, L. (2011) Long-term outcome in medical patients aged 80 or over following admission to an intensive care unit. Critical Care, 15, R36.

[2] Garrouste-Orgeas, M., Timsit, J.F., Montuclard, L., Colvez, A., Gattolliat, O., Philippart, F., Rigal, G., Misset, B. and Carlet, J. (2006) Decision-making process, outcome, and 1-year quality of life of octogenarians referred for intensive care unit admission. Intensive Care Medicine, 32, 1045-1051. http://dx.doi.org/10.1007/s00134-006-0169-7

[3] Garrouste-Orgeas, M., Boumendil, A., Pateron, D., Aergerter, P., Somme, D., Simon, T. and Guidet, B. (ICECUB Group) (2009) Selection of intensive care unit admission criteria for patients aged 80 years and over and compliance of emergency and intensive care unit physicians with the selected criteria: An observational, multicenter, prospective study. Critical Care Medicine, 37, 2919-2928. http://dx.doi.org/10.1097/CCM.0b013e3181b019f0

[4] Boumendil, A., Somme, D., Garrouste-Orgeas, M. and Guidet, B. (2007) Should elderly patients be admitted to the intensive care unit? Intensive Care Medicine, 33 1252-1262. http://dx.doi.org/10.1007/s00134-007-0621-3

[5] Boumendil, A., Aegerter, P., Guidet, B. and CUB-Rea Network (2005). Treatment intensity and outcome of patients aged 80 and older in intensive care units: A multicenter matched-cohort study. Journal of the American Geriatrics Society, 53, 88-93.

http://dx.doi.org/10.1111/j.1532-5415.2005.53016.x

[6] Guerin, C., Girard, R., Selli, J.M., Perdrix, J.P. and Ayzac, L. (2000) Initial versus delayed acute renal failure in the intensive care unit. American Journal of Respiratory and Critical Care Medicine, 161, 872-879. http://dx.doi.org/10.1164/ajrccm.161.3.9809066

[7] Hamel, M.B., Davis, R.B., Teno, J.M., Knaus, W.A., Lynn, J., Harrell Jr., F., Galanos, A.N., Wu, A.W. and Phillips, R.S. (1999) Older age, aggressiveness of care, and survival for seriously ill, hospitalized adults. Annals of Internal Medicine, 131, 721-728.

http://dx.doi.org/10.7326/0003-4819-131-10-199911160$\underline{00002}$ 
[8] Djaiani, G. and Ridley, S. (1997) Outcome of intensive care in the elderly. Anaesthesia, 52, 1130-1136. http://dx.doi.org/10.1111/j.1365-2044.1997.237-az0369.x

[9] Esteban, A., Anzueto, A., Frutos-Vivar, F., Alía, I., Ely, E.W., Brochard, L., Stewart, T.E., Apezteguía, C., Tobin, M.J., Nightingale, P., Matamis, D., Pimentel, J., Abroug, F. and Mechanical Ventilation International Study Group (2004) Outcome of older patients receiving mechanical ventilation. Intensive Care Medicine, 30, 639-646. http://dx.doi.org/10.1007/s00134-004-2160-5

[10] Rellos, K., Falagas, M.E., Vardakas, K.Z., Sermaides, G. and Michalopoulos, A. (2006) Outcome of critically ill oldest-old patients (aged 90 and older) admitted to the intensive care unit. Journal of the American Geriatrics Society, 54, 110-114. http://dx.doi.org/10.1111/j.1532-5415.2005.00544.x

[11] de Rooij, S.E., Govers, A., Korevaar, J.C., Abu-Hanna, A., Levi, M. and de Jonge, E. (2006) Short-term and longterm mortality in very elderly patients admitted to an intensive care unit. Intensive Care Medicine, 32, 1039-1044. http://dx.doi.org/10.1007/s00134-006-0171-0

[12] Rockwood, K., Noseworthy, T.W., Gibney, R.T., et al. (1993) One-year outcome of elderly and young patients admitted to intensive care units. Critical Care Medicine, 21, 687-691. http://dx.doi.org/10.1097/00003246-199305000-00011

[13] Nicolas, F., Le Gall, J.R., Alperovitch, A., Loirat, P. and Villers, D. (1987) Influence of patients' age on survival, level of therapy and length of stay in intensive care units. Intensive Care Medicine, 13, 9-13. http://dx.doi.org/10.1007/BF00263549

[14] Vosylius, S., Sipylaite, J., Ivaskevicius, J. (2005) Determinants of outcome in elderly patients admitted to the intensive care unit. Age and Ageing, 34, 157-162. http://dx.doi.org/10.1093/ageing/afi037

[15] Chelluri, L., Pinsky, M.R., Donohoe, M.P. and Grenvik, A. (1993) Long-term outcome of critically ill elderly patients requiring intensive care. JAMA, 269, 3119-3123. http://dx.doi.org/10.1001/jama.1993.03500240063027

[16] Mayer-Oakes, S.A., Oye, R.K. and Leake, B. (1991) Predictors of mortality in older patients following intensive care: The importance of functional status. Journal of the American Geriatrics Society, 39, 862-868.

[17] Boumendil, A., Maury, E., Reinhard, I., Luquel, L., Offenstadt, G. and Guidet, B. (2004) Prognosis of patients aged 80 years and over admitted in medical intensive care unit. Intensive Care Medicine, 30, 647-654. http://dx.doi.org/10.1007/s00134-003-2150-Z

[18] Esteban, A., Anzueto, A., Frutos-Vivar, F., Mechanical Ventilation International Study Group, et al. (2004) Outcome of older patients receiving mechanical ventilation. Intensive Care Medicine, 30, 639-646. http://dx.doi.org/10.1007/s00134-004-2160-5

[19] Castillo-Lorente, E., Rivera-Fernandez, R., Vazquez-Mata,
G., et al. (1997) Limitation of therapeutic activity in elderly critically ill patients. CCM, 10, 1643-1648. http://dx.doi.org/10.1097/00003246-199710000-00012

[20] Walther, S.M. and Jonasson, U. (2004) Outcome of the elderly critically ill after intensive care in an era of cost containment. Acta Anaesthesiologica Scandinavica, 48, 417-422. http://dx.doi.org/10.1111/j.0001-5172.2004.00355.x

[21] Somme, D., Maillet, J.M., Gisselbrecht, M., Novara, A., Ract, C. and Fagon, J.Y. (2003) Critically ill old and the oldest-old patients in intensive care: Short- and long-term outcomes. Intensive Care Medicine, 29, 2137-2143.

[22] Hamel, M.B., Davis, R.B., Teno, J.M., et al., for the SUPPORT Investigators (1999) Older age, aggressiveness of care, and survival for seriously ill, hospitalized adults. Annals of Internal Medicine, 131, 721-728. http://dx.doi.org/10.7326/0003-4819-131-10-199911160$\underline{00002}$

[23] Vaughan, R.W. (2001) The "age wave": America's tsunami of the future? ASA Newsletter, 65, 20-24.

[24] Zhou, G.P., Song, Y.X. and Zhao, Z.J. (2005) Efficiency of APACHE II and III scoring system in the prognostication of patients older than 75 years. Chinese Journal of Internal Medicine, 44, 251-253.

[25] Quach, S., Hennessy, D.A., Faris, P., et al. (2009) A comparison between the APACHE II and Charlson Index Score for predicting hospital mortality in critically ill patients. BMC Health Services Research, 9, 129. http://dx.doi.org/10.1186/1472-6963-9-129

[26] Schönhofer, B., Guo, J.J., Suchi, S., et al. (2004) The use of APACHE II prognostic system in difficult-towean patients after long-term mechanical ventilation. European Journal of Anaesthesiology, 21, 558-565.

[27] Sakr, Y., Krauss, C., Amaral, A.C., et al. (2008) Comparison of the performance of SAPS II, SAPS 3, APACHEII, and their customized prognostic models in a surgical intensive care unit. British Journal of Anaesthesia, 101, 798-803. http://dx.doi.org/10.1093/bja/aen291

[28] Mbongo, C.L., Monedero, P., Guillen-Grima, F., et al. (2009) Performance of SAPS3, compared with APACHII and SOFA, to predict hospital mortality in a general ICU in Southern Europe. European Journal of Anaesthesiology, 26, 940-945. http://dx.doi.org/10.1097/EJA.0b013e32832edadf

[29] Funk, G.C., Lindner, G., Druml, W., et al. (2010) Incidence and prognosis of dysnatremias present on ICU admission. Intensive Care Medicine, 36, 304-311. http://dx.doi.org/10.1007/s00134-009-1692-0

[30] Stelfox, H.T., Ahmed, S.B., Khandwala, F., Zygun, D., Shahpori, R. and Laupland, K. (2008) The epidemiology of intensive care unit-acquired hyponatraemia and hypernatraemia in medical-surgical intensive care units. Critical Care, 12, R162. 